\title{
The Opportunities and Challenges of the Reconstruction of Buddhist Charity Thought
}

\author{
Fu Yunshu \\ Marx School of Philosophy, Hebei University of Technology, Tianjin 300401, China
}

Keywords: Buddhist charity thought; reconstruction; opportunity; challenge

\begin{abstract}
Buddhism has always been adhering to the fine tradition of patriotism, love of teaching and keeping pace with the times, and the Buddhist theory still has a certain role in social education. Reconstruction of the traditional Buddhist charity thought is one of the opportunities and challenges of the joint efforts of government, business, need teaching and learning realms, Buddhism as a subject in need Chinese socialist theory of religion and religious work of the party and the government on the latest strategy, based on the present situation in China, the level of productivity and the needs of the people, mining and social development of $\mathrm{Fu}$ Shun will give up to the connotation of social development.
\end{abstract}

\section{Introduction}

General Secretary Xi Jinping mentioned in the 2015 meeting of the central United Front work that China's religion must adhere to the orientation of China, and religious work must improve the level of rule of law. This points out the direction for the construction of religious theory and religious work. Because of the conservative and lagging religious theory development, Buddhist charity thought must be through Qucuqujing processing and returning to the new interpretation.

\section{The connotation of Buddhist charity thought}

In Buddhist doctrine and doctrine, there is no clear concept of charity, nor a complete set of philanthropic ideas. From the current scholars' research, the Buddhist charity thought is integrated with the Buddhist ethics as a whole. In his article "Reflections on Buddhist charity", Chen Xingqiao summed up the connotation of Buddhist charity as "mercy without mercy" and "virtue and virtue". The main content is reflected in "four immeasurable mind" and "four photography"". [1] Yu Richang in the "Buddhist charity" 3 "' the Buddhist charity thought connotation summarized as the heart of infinite compassion and mercy, virtue, schlie cloth is the only proper course to take his virtue [2]. Lin Zhigang proposed the [3] Chinese Buddhist charity Fangxing structure theory in "Chinese theory" of the Buddhist charity, the origin of law as the theoretical foundation of compassion as the core of the theory of karma value statute, giving view to practice the path, Fukuda said as value direction, which is currently in the literature for the first time according to the system theory the induction of Buddhist charity theory.

From the Buddhist theory and the doctrine of the word charity is a modern society of classical and not for Buddhist system interpreted as charity, but there is a set of relatively complete interpretation system for mercy, compassion in Buddhism is a kind of pay never get paid a high level of spiritual realm, so we can find the corresponding charity in Buddhism theory interpretation, Mahayana Buddhism Charity thought is mainly divided into two parts of charity and charity, mercy that compassion, good deeds are in accordance with the dharma. Buddhist charity thought involves three aspects of spirit, material and culture, and embodies the Buddhist doctrines of compassion and Tetra Pak people. The theoretical basis of Buddhist charity thought is mainly the Bodhi concept, idea, generosity, compassion at the Futian and gratitude idea. 


\section{The essence of Buddhist charity thought and not adapt to the social development section}

At present, the domestic evaluation and localization of Chinese traditional religious culture is not complete, so we need to grasp the relationship between Buddhist charity culture and Marx advanced culture, and the traditional Chinese culture. Buddhist charity thought is a kind of religious charity theory. Compared with charity at the national and folk levels, Buddhist charity thought transcends secular values in providing spiritual charity in terms of ideas and confidence. This idea is based on the resources of Buddhist organizations, temples and monks, so the Buddhist charity thought to be core tradition, wind construction depends on temple and monks in Qin Xiu, is, and social harmony, to serve the development of the society.

\subsection{The essence of Buddhist charity thought}

The essence of play Buddhist charity thought, analysis of promoting the revival of traditional culture of the first need to discard the dross and select the essential for the traditional Buddhist charity thought, which is mainly accord with socialist core value extraction of traditional Buddhist charity thought in view of social ethics requirements, in accordance with the Chinese traditional culture connotation of the essence of the core. There are three main advantages: Buddhist charity thought is rooted in the inherent demand of Buddhist charity, and other non utilitarian exchange value; Buddhist charity thought about compassion, help sentient beings are not for the return of the spirit of selfless dedication; Buddhist charity is not only to solve the shortage, more important is to appease the heart give relief and help their spirits, is the heart and soul of charity relief. The essence of Buddhist charity thought is mainly reflected in the promotion of people and their own moral harmony in the five precepts, ten good, four camera, six degree concept, compassion, filial piety, stop thought good coordination of social harmony, equality, harmony [5] Road, the origin of the theory of embodiment of human and nature, and patriotism, solemn land and promote Buddhism and the socialist state power of harmony. The construction of a harmonious society includes the fields of political, economic and cultural development. "Harmonious society" includes three aspects: human and self, human and society, and the harmony between man and nature. The most important thing is to coordinate the harmonious [6] of social relations. The Buddhist Sangha theory of Buddhism in Liuhe has certain value for the harmony of social relations. Among them, "to do the same with", "see with the reconciliation", "benefit and harmony" are the internal core of harmony, while the norms of behavior, the value of the statute, the balance of interests is the deep nature of social relations harmony. The following will discuss the theoretical contribution of Buddhist charity thought to the balance and coordination of social relations from three aspects: "Qu", "Ming", "Li" and "Li".

\subsection{The Buddhist charity thought is not suitable for social development section}

Buddhist charity thought can not be compatible with the harmonious society in any way, and its positive role can not be exaggerated. A Buddhist charity thought and the whole Buddhist theory can not be cut. Buddhist theory itself is pessimistic idealism, the traditional Buddhist charity thought is self-centered on merit karma "small charity", and not to serve others and the society as the most important goal. Second, the Buddhist charity thought on the origin and merit based beliefs, but for no faith or not to open the basis of Buddha Buddhist charity thought, regulate and restrict the limited role, simply go to the letter to do may lead to obtain the direction of merit. Third, a conservative and lagging of theory of religion as a cultural development, subordinate and part of social public morality can not become the mainstream spirit of China's economic and social development support can not become a social public moral standard.

\section{The opportunities and challenges of the reconstruction of Buddhist charity thought}

From the provision of laws, regulations and policies, as well as the tolerant and harmonious political environment, the party and government support and encourage the religious community to carry out charitable activities and the principle of theoretical construction has been clear. In order to serve today's society, Buddhist charity thought must not forget to start a new interpretation, instead of 
simply copying the ancients.

\subsection{The opportunity of reconstruction of Buddhist charity thought}

"Opinions on encouraging and regulating the religious community in public welfare activities" is a policy guidance especially for the public welfare activities issued by religious circles. The eighteen major points of the party also clearly pointed out that we should play the role of religious circles and believers in promoting economic and social development." In addition, the general secretary $\mathrm{Xi}$ Jinping UNESCO published on the exchange and development of world civilization in a speech on religious ethics has made positive and objective evaluation of the United Nations: "deep and complete religious ethics, strengthen the moral function of some". The central United Front Work Meeting of 2015 General Secretary Xi Jinping to actively guide religions to adapt to socialist society and put forward new requirements: "we must insist on the direction of China, must improve the level of the rule of law and religion, social function must be a dialectical view of religion, religious people must pay attention to the role of guiding the religious efforts to promote economic development and social harmony, cultural prosperity, national unity, the unity of the motherland service". In the 2016 National Conference on religion, the Communist Party and the government Chinese theoretical depth China for actively guide religions to adapt to socialist society and the development, adhere to the direction of Chinese proposed religion is the religious work to improve the level of the rule of law is an important guarantee of religious work, and actively explore the theory of religion is the important task of religious China, to the socialist core values as a guide, encourage religious people to play an active role in the economic, cultural and social development, national unity, national unity and other aspects, to promote the construction of five civilizations, for the early realization of the "two one hundred year" goal to contribute positive energy.

The background of the judgment of the social value of benevolence and good thought in Buddhism is based on the modern context. From the perspective of human nature of good and evil, tend to Buddhist theory of good, the French sociologist Comte is a representative of the western rationalism, but Comte thought the religious emotion and ethics helps to overcome human selfishness and altruism, good support for supporting a religion helps to maintain people's moral bottom line, stimulate the goodness of the heart so as to maintain the integrity of human nature. From the point of view of the law of historical development, the social division of labor will inevitably bring about the separation of church and charity, the future China Buddhist charity towards social development, gradually clear role and responsibilities of religious charities and social charity organizations. But from the current point of view, China will encourage and guide the religious charity organization to carry out the social services and the cultural reconstruction theory, which shows the value of educational function of religious charity thought can play in today's society, there are areas of religious charity charity service can be used as a feature of the. At present, religious charity is the opportunity for development, the Buddhist community should recognize the current situation, positive and promising, seriously study the relevant laws and policies, and strive to build a harmonious society in spirit and action. Specifically, the fundamental Buddhist charity thought to play an active role in the harmonious society is the political identity, always adhere to the leadership of the party, to establish the Chinese characteristics of Buddhist charity thought as the goal, adhering to the tradition of patriotism, abide by laws and regulations. Secondly, from the perspective of culture, construction of charity thought characteristic Chinese to Buddhism returning to the new, both back by theory and combined with the classic monk theory formulation of new practice development. Finally, from the perspective of social education, Buddhist charity thought should pay attention to its own characteristics, play spiritual charity and other unique values of social education.

\subsection{The challenge of the reconstruction of Buddhist charity thought}

In the history of the traditional centralized official standard form of society and society based on patriarchal kinship relations, including the impact of state system, laws and regulations on the implementation of the superstructure, the degree of Buddhism for Buddhist charity, subject, in the subject to physical form and social form. First of all, Chinese Mahayana Buddhist charity thought in 
"compassion" and "altruistic" concept represents true selfless dedication, pay without asking for a high level of spiritual realm, in real life, people only dream of, the public are often for Buddhist charity thought cannot be completely absorbed, "Salford" and "merit" concept may in Buddhist circles and religious believers to charity casual and temporary tendency, which makes the practice and reality of Buddhist charity thought out. Secondly, the Buddhist culture belongs to the marginal culture, the mainstream ideology of Buddhist charity thought origin empty world view and free Buddha's ultimate goal and scientific atheism does not match. From the historical point of view, Buddhism for each stage of care and social development are shining sparks of wisdom, the traditional Buddhist charity activities of many, but few have formed a certain amount and scale of the situation, for the Buddhist charity thought essence inheritance and transformation of innovation is a major challenge to contemporary Buddhism Buddhist charity thought reconstruction. Buddhist charity thought can be closely linked to the theme of the times, as the "mainstream" development provides another perspective is that to a large extent the "processing" the level of supervision and administration requirements of both Buddhist circles political literacy, knowledge level and moral quality is also a test of the government during the boot process, but also depends on the perfection of legislation. It should be noted that "opinions" stressed that "religion should not be spread in public charity activities."'. The essence of spirit is to grasp the relationship between the unity of opposites, on the one hand, to weaken the external form of religious belief, on the other hand, to carry out the belief and strengthen the spirit of compassion and salvation. The best way to play the best role of religious charity lies in the altruistic spirit of charity activities, truly embodies the nature of faith and identity. Finally, from the perspective of causal pluralism, building a harmonious society really need to own traditional culture roots, to learn the essence of essence from Buddhist charity thought. However, the construction of a harmonious society lies not only in the construction of culture or ideology, but also in the construction of material and institutional aspects, which is the guarantee of politics, economy and law. The Buddhist charity thought there is some relief for the contradiction between man and self, man and nature, man and society, but the "extra," perseverance ", a kernel, a country of Xingren". The value of Buddhist charity thought for the construction of a harmonious society needs to be dialectically considered.

\section{Conclusion}

Buddhist charity in the thought of "compassion" and "altruistic" essence thought in today's social education still has a role, contribute to the promotion of their own moral harmony, balance and coordination of social relations and promote the formation of good habits of the poor, the selfless dedication of the. The party and the government should play a leading role in talents cultivation and constantly improve the relevant religious affairs management, encourage, support and guide the Buddhist circles to enhance learning and communication, enhance political literacy and education level; Buddhism play the main role, face the existing problems, clear the value of traditional Buddhist charity thought, including inheritance the essence, discard and does not conform to the connotation of socialist core values, which will contribute to social harmony and progress of the times and the connotation of healthy and civilized life, specific interpretation, combined with the practice of Buddhist charity activities to enrich the Buddhist charity thought. In addition, society and academia need to jointly promote the objective positioning, scientific evaluation, processing reconstruction and era innovation of Buddhist charity with Chinese characteristics. Starting from the spirit of general secretary Xi Jinping's 2016 speech at the National Conference on religion, exploration and reconstruction theory of religion is an important starting point of religious Chinese, the Buddhist community should seize the opportunity, positive and promising, pay attention to the construction of Buddhist charity theory, take the initiative to carry out the ideological and cultural construction and self construction in socialist core values under the guidance of continue to reflect their own the value of culture, morality, social work through social services, forming a virtuous cycle with the government and society, the Buddhist charity thought better to build a harmonious society to play an active role. 


\section{References}

[1] Opinions on encouraging and regulating religious circles in public welfare activities [J]. Chinese religion, 2012, (10): 30-33.

[2] Experience. A theoretical system of [J]. China Buddhist charity culture, world religions, 2012, (05): 51-57.

[3] Chen loss. On the fine, some thoughts of Buddhist charity [J]. 2011, (11): 43-50.

[4] Jia Junfeng. The concept of harmony in Buddhism thought in contemporary [D]. Hebei Normal University, 2008.

[5] More than three Buddhist charity. [J]. Xuehai, 2007, (06): 78-80.

[6] Fang Litian. The construction of the harmonious society and the role of religion [J]. Chinese religion, 2005, (07): 18-19. 